\title{
Directive Illocutionary Act in PUNK community at Lubuk Pakam
}

\author{
Roma Ayuni A. Loebis ${ }^{1}$, Wan Syaifuddin ${ }^{2}$ \\ $\left\{{ }^{1}\right.$ roma@usu.ac.id, ${ }^{2}$ syaifuddin@usu.ac.id\} \\ ${ }^{\mathbf{1}}$ English Literature Department, Faculty of Cultural Science, University of Sumatera Utara \\ ${ }^{2}$ Malay Studies Program, Faculty of Cultural Science, University of Sumatera Utara
}

\begin{abstract}
Directive Illocutionary Act often which occur during informal conversation, such in conversation among family members or close friends. This act also occur among young people who claimed their selves as members of PUNK community in Lubuk Pakam, Deli Serdang, North Sumatera, Indonesia. They are gathered because they have same philosophy of life. Commonly, they are teen-agers who come from various part of Indonesia, such as Aceh, Sumatera, Java, Bali and other regencies. Directive Illocutionary act is chosen because this speech act are mostly used as strategic communication in their daily activities such as commanding, questioning, requesting and forbidding. The purpose of this analysis is to find out kinds of Directive Illocutionary act that mostly expressed among members of PUNK community. This analysis used Pragmatic theory with Speech Act approach and apply descriptivequalitative method. The data are the utterances which were recorded from their daily conversation. The result showed that commanding (55 utterances) and questioning (50 utterances) are used more often than permitting (23 utterances), suggesting (20 utterances), forbidding (17 utterances), encouraging (11 utterances) and requesting (10 utterances).
\end{abstract}

Key words: Directive Illocutionary Act, PUNK community, Speech Act

\section{Introduction}

A good communication needs a two way comprehension or understanding between the speaker and the hearer. In attempt to express his intention, the speaker's utterance should not only contain grammatical features, but also it has to contain function. Some speakers might utter in various way which cause confusion for the hearer. In that case, context plays great role in clearing the intention. Regarding to communication, Speech Act is the basic unit of communication. By doing speech act, the speaker tries to convey purpose or intention of communication. Speech act [1] [2] [3] is an action such as making statement, giving orders, asking questions, making appointments etc. and this action generally made possible by and conducted in accordance with certain rules for the use of linguistic elements. Speech act theory has been developed by British philosopher, John Searle. There are five basic kinds of action or illocution of utterance that one can perform in speaking which are promoted by Searle [4], and they are: (1) Representative, (2) Directive, (3) Commissive , (4) Expressive and (5) Declarative. From above categories, the researcher focuses on the Directive 
Illocutionary Act because this research aims to the using of this act among members in PUNK community in Lubuk Pakam. Directive Illocutionary act is type of speech act which the intention of speaker is to order or ask the hearer to do something. Searle groups the directive illocutionary into 8 (eight) kinds. Commanding; is the function used to ask or order someone to do something in direct way. It is usually done by the powerful one to powerless one. Requesting; can be defined to ask or to order someone to do something in indirectly or polite way. By asking a request, the hearer has the right to refuse or deny it. In other word, the hearer has the choice either to accept or to reject the request. Suggesting; can be defined as what the speaker purpose to get the hearer to do something in future action. It also can be an act performed by the speaker for the hearer by attaching or putting forward an idea or plan to think about it. Forbidding; is used usually to ask or order someone not to do something. It can be defined that the speaker prohibits the hearer from doing an act. Questioning; This illocutionary function is expressed by the speaker in order to get a reply, answer, or information from the hearer. Permitting; includes agree to, allow, authorize, bless, consent to, forgive, release. Encouraging; can be defined that the speaker gives the hearer support or encouragement to do something. Wishing; can be defined that the speaker hopes something good to happen in the future. Some previous research on directive Illocutionary act have been done, such on Local language by [5]Kundharu Saddhono (2016), on English teacher by [6] Husnol Wafa (2017), on Holy Quran English translation by [7] Hapikry Surya, on movie script by [8]Fita Nur Rahayu (2018), and on daily conversation by [9] Mahdalena (2018)

Commonly known, young people who belong to PUNK community are regarded as person with reckless, harsh and bad character. PUNK, the abbreviation of People United Not Kingdom is the stream which arouse in London as the form of rebellion from group of people who stand against the Kingdom regulation. They promoted their freedom by wearing extreme clothes, dyed their hair and styled their hair like Mohawk (Indian tribes). In Indonesia young people who claim they have the same philosophy of life, same interest, same background, and same commitment. Moreover, they build community which called PUNKER. Basically they wear black shirt, black tight pants, black boots and black leather jacket [10]. With piercing on their faces (eyelash, nose, lips) and tattoo on their bodies as they claimed that is a symbol of freedom. In communicating, this community members use informal language. Informal words [9] are used when talking to the family, relatives, neighbor, and friends in meal time, break session at school, at work or among collegues. As language is a product of social behavior, the researcher interest in analyzing their speech act in using directive illocutionary act and which act is mostly used by the member of PUNK community in Lubuk Pakam, Deli Serdang, North Sumatera Indonesia. This community consist of various teenagers and young people (age between 16 to 25) who come from various town in Indonesia, such Aceh, Padang, Palembang, Jember, Bekasi, Bandung. They all gather in Lubuk Pakam because of the same philosophy of life, that is sama rasa walau tak sebaya (have same feeling although different in age). Some of them came from a broken home family and stay in one place to another. They get connected to each other mostly by social media such as Face Book (FB) [11].

\section{Research Method}

In doing this research, researcher uses mixed method. Mixed method [12] is a research design that uses both qualitative and quantitative method. Data is collected by recording and applying simak bebas libat cakap or techique which is used to observe the speech used by 
PUNK community when they communicate with each other but the reseracher does not participate in the conversation in order to get natural conversation. The conversations are recorded for 3 hours every Sunday on 6th, 13th, 20 ${ }^{\text {th }}$ and 27th July 2019 when the community members gathered in the traffic light on jalan Perintis Kemerdekaan intersection, Lubuk Pakam. The data reduction [13] refers to the process of selecting, focusing, simplifying, abstracting, and transforming the data that appeared in written field notes or transcription. The researcher selected and categorized the data based on directive speech act theory and the directive illocutionary function approach.

\section{Results And Discussion}

In this research the analysis is conducted in three steps. Firstly, reduction of the data, the whole conversation will be reduced to only the directive illocutionary. Secondly, displaying the data that is grouping the data based on the eight kinds of directive illocutionary act. Finally, verification by giving more explanation about the displayed data.

From the recorded conversation, 315 utterances are reduced into eight kinds of directive illocutionary act, but only seven kinds are noticed. Wishing is not found in the utterance.

Table 1. Name of members who are recorded using Directive Illocutionary Act

\begin{tabular}{llllllll}
\hline No. & Name & Gender & Age & No. & Name & Gender & Age \\
\hline 1. & Diky (D) & Male & 20 & 13. & Martin (M) & Male & 22 \\
2. & Ali (A) & Male & 16 & 14. & Jojo (J) & Male & 23 \\
3. & Ben (B) & Male & 24 & 15. & Samuel (S) & Male & 19 \\
4. & Tia (T) & Female & 17 & 16. & Afif (Af) & Male & 23 \\
5. & Fani (F) & Female & 17 & 17. & Amrin (Am) & Male & 20 \\
6. & Amansyah (A) & Male & 21 & 18. & Yoga (Y) & Male & 25 \\
7. & Simon (S) & Male & 18 & 19. & Fahmi (F) & Male & 22 \\
8 & Iwan (I) & Male & 22 & 20. & Sahrul (S) & Male & 23 \\
9. & Jon (J) & Male & 16 & 21. & Tasya (Ty) & Female & 20 \\
10. & Zulpan Z) & Male & 20 & 22. & Sakti (Sk) & Male & 20 \\
11. & Mora (M) & Male & 24 & 23. & Dame (Dm) & Female & 20 \\
12. & Nita (N) & Female & 19 & 24. & Sapta (Sp) & Male & 25 \\
\hline
\end{tabular}

Data 1

A: "Om..seribu om..untuk makan"

(Sir..please give me one thousand for food)

Situation: when A requesting toward driver who stopped in red light to give him money.

Data 2.

D: "Besok kau aja yang beli..ya"

(Tomorrow you buy )

Situation: when D commanding A to buy him food

Data 3.

T: "Jangan jauh kau maen... ditangkap kau nanti"

(Do not go too far..you will be caught)

Situation: when $\mathrm{T}$ forbidding $\mathrm{F}$ to go far from the group 
Data 4.

B: "Ambil lah tapi jangan banyak banyak. Yang laen belom dapat"

(Take it but not too much. Other has not get it yet)

Situation: when B permitting $\mathrm{J}$ to take some fried food

Data 5.

T: "Kurasa besok kita ikut aja nengok kaos ke Medan"

(I think we should go Medan to see the T-Shirt)

Situation: when T suggesting her friends to go to Medan to see the T-Shirt production

Data 6.

B: "Lek, udah kau bagi duit tadi?"

(Brother..have you gave the money?)

Situation: when B asking information from D about the money

Data 7.

N: "Mintak sama si Pen “

(Ask Pen)

Situation: when $\mathrm{N}$ commanding $\mathrm{D}$ to ask $\mathrm{Z}$ for a cigarette

Data 8

S: "Lebih bagus kalo kita minta ajarin nyablon kaos sama bang Ran. Nyablon banyak untungnya"

(We ask bang Ran to teach us to paint the T-Shirt. We can earn a lot from screen printing) Situation: when S suggesting her friends to ask brother Ran to teach them how make screen printing on the T-Shirt

Data 9

B: "Nggak boleh kau betato" (You are forbidden to have tattoo)

Situation: when $\mathrm{B}$ forbidding $\mathrm{T}$ to have tatoo

F: "Kakak aja yang minta. Kalau yang minta kakak, dikasinya itu"

(Sister should ask for that. If sister ask, he will give)

Situation: when $\mathrm{F}$ suggesting $\mathrm{T}$ to ask $\mathrm{B}$ for money

Data 10

U: "Keknya bagusan kau beli yang perak la" (Think you should buy the silver one)

Situation: when $\mathrm{U}$ suggesting $\mathrm{Z}$ to buy silver necklace

Data 11

B: "Belikan aku rokok dulu" (Buy me cigarettes)

Situation: when $\mathrm{Z}$ commanding $\mathrm{J}$ to buy cigarettes

Data 12

T: "Tolong bawakan ini"'(handing two ukulele=small guitar) (Please help me to carry these)

Situation: when $\mathrm{T}$ requesting $\mathrm{M}$ to carry two ukulele

Data 13

Z: "Dari Jember naik apa bang?" 
(By what did you came from Jember?)

Situation: when $\mathrm{Z}$ questioning $\mathrm{A}$

Data 14

A: "Udah pernah kelen nonton musik ke Medan?"

(Have you all watched live music in Medan?)

Situation: when A questioning his friends

Data 15

S: "Jumpa kita di skenan besok ya" (skenan=place to gather)

(Tomorrow we will meet at the point base)

Situation: when $\mathrm{S}$ commanding his friends

Data 16

D: "Ambil aja..kok takut kau. Ambil..ambil"

(Take it..don't be afraid. Take it)

Situation: when D encouraging A to take something

Data 17

I: "Gerak woi"

(Let's go)

Situation: when I commanding his friends

Based on the recorded conversation, 315 utterances are reduced into eight kinds of directive illocutionary act, but only seven kinds are noticed. Wishing is not found in the utterance.

Table 2. The spread of Directive Illocutionary Act

\begin{tabular}{lll}
\hline No. & Kind of Directive Illocutionary Act & Utterances \\
\hline 1. & Commanding & 55 \\
2. & Requesting & 10 \\
3. & Suggesting & 20 \\
4. & Forbidding & 17 \\
5. & Questioning & 50 \\
6. & Permitting & 23 \\
7. & Encouraging & 11 \\
8. & Wishing & 0 \\
\hline
\end{tabular}

From the data it can be seen that commanding are uttered more often than other kinds of directive illocutionary act. It is mostly expressed by older person to the younger one. Although they have an understanding that they are equal, which means nobody is superior than otherstill in communication discovered that the older one often do the command. The younger one in a some situation made the questions. Some questions to the older one and some questions to the equal ages. Questioning is also often uttered because when they are gathered, they usually exchange experiences and exchange new information. On the other hand, the use of suggesting and requesting from girls indicates the gender differences. Girls in the community are less in giving command or forbidding some one. This might due to the minority in numbers. They are likely to suggest or to request. Forbidding also uttered by the older person with the purpose of protecting and warning their friends. They are also likely to encourage their friends. Mostly they speak to each other directly to the point in order to gain clear communication as they do not want to hide something behind their back. This is assumed that they hold philosophy of life: solidarity and togetherness. 


\section{Conclusion}

PUNK community members in Lubuk Pakam, Deli Serdang, North Sumatera Indonesia are dominant with teenagers with various background. They are who do not have enough education, have less attention from parents or just a victims of a broken home family. Their dissatisfaction and rebellion are reflected in their performance such as piercing their face or dying their hair and wearing improper clothes. That also impact to their way of communication. They are likely speak directly or use direct way of speech. Their philosophy of life are freedom, solidarity and togetherness. All are reflected in 7 (seven) kinds of directive illocutionary act. Only wishing never uttered. Hence, future analysis is needed to observe this phenomenon. Probably this also because they only live and think for today and never worry about what will happen on the next day.

\section{Acknowledgement}

This research was supported by University of Sumatera Utara under contract of Research Implementation Talenta USU, number: 4167/UN5.1.R/PPM/2019 dated 01 April 2019

\section{References}

[1] S. Levinson, "Pragmatics - part 1 of 2," pp. 1-9, 2011.

[2] H. H. Abood, "Offering as A commisive and Directive Speech Act: Consequence for CrossCultural Communication," Int. J. Sci. Res. Publ., vol. 2, no. 2, 2012.

[3] A. Dylgeri, "Analysis of speech Act in Political Speeches," Eur. J. Soc. Sci., vol. 2, no. 2, 2017.

[4] S. John R, An Essay in The Philosophy of Language. Cambridge: Cambridge University Press, 1969.

[5] K. Saddhono and F. Kasim, "The Form and Function of Local Language in Directive Speech Act at A University in Central Sulawesi," Ling. Cult., vol. 10, no. 1, p. 37, 2016.

[6] Wafa \& Indrawati Vahmita, "Directive Illocutionary Act on English Teacher in Elementary School Sukoharjo 3 Probolinggo (Pragmatics Study)," Metathesis, vol. 1, no. 1, pp. 119-129, 2017.

[7] H. S. Permana and E. Citraresmana, "Directive Illocutionary Acts Used in the English Translation of the Holy Quran by Muhammad Asad: A Corpus Based Study," he 6th Int. Conf. Multidiscip. Res., pp. 582-589, 2017.

[8] F. N. Rahayu, M. B. Arifin, and S. Ariani, "Illocutionary Act in the Main Characters '," vol. 2, no. 2, pp. 175-187, 2018.

[9] M. I. Indrawan, "Koleksi Buku 2012 Jendra , Made Iwan Indrawan " Sociolinguistics : the study of societies ' languages / Made Iwan Indrawan Jendra " 2012," p. 2012, 2012.

[10] J. P. Sosiologi, "Jurnal Pendidikan Sosiologi 2017 Page 1," no. 4, pp. 1-15, 2017.

[11] A. Septiadi, Hendi; Octaviani, Vethy; Imanda, "Pola Komunikasi Antar Anggota Komunitas Anak Punk," vol. 3, no. 3, 2016.

[12] H. Hardiansyah, Metodologi Penelitian Kualitatif. Jakarta: Salemba Humanika, 2010.

[13] M. B. and A. M. H. Miles, Qualitative data Analysis: A Method Source Book. London, United Kingdom: SAGE Publication, 2014. 